\title{
Vector-borne zoonotic blood parasites in wildlife from Ecuador: A report and systematic review
}

\author{
Eduardo Diaz'iD, Anahi Hidalgo1(i), Carla Villamarin²(iD, Gustavo Donoso1(i) and Veronica Barragan ${ }^{2,3}$ (iD) \\ 1. Escuela de Veterinaria, Hospital de Fauna Silvestre TUERI, Universidad San Francisco de Quito, Quito, Ecuador; \\ 2. Colegio de Ciencias Biologicas y Ambientales, Instituto de Microbiologia, Universidad San Francisco de Quito, \\ Quito, Ecuador; 3. Department of Biological Science, Pathogen and Microbiome Institute, Northern Arizona University, \\ Flagstaff, USA. \\ Corresponding author: Veronica A. Barragan, e-mail: vbarragan@usfa.edu.ec \\ Co-authors: ED: eadiaz@usfq.edu.ec, AH: ana.hid.cor@gmail.com, CV: cvillamarinu@usfq.edu.ec, \\ GD: gus_1394@hotmail.com \\ Received: 09-04-2021, Accepted: 10-06-2021, Publisher online: 27-07-2021
}

doi: www.doi.org/10.14202/vetworld.2021.1935-1945 How to cite this article: Diaz E, Hidalgo A, Villamarin C, Donoso G, Barragan V (2021) Vector-borne zoonotic blood parasites in wildlife from Ecuador: A report and systematic review, Veterinary World, 14(7): 1935-1945.

\begin{abstract}
Background and Aim: Ecuador is a hugely diverse country, but information on infectious diseases in local wild animals is scarce. The aim of this study was to screen the presence of blood parasites in free-ranging wild animals admitted to the Wildlife Hospital at Universidad San Francisco de Quito, from April 2012 to January 2019.

Materials and Methods: We identified blood parasites by microscopic observation of blood smears from free-ranging wildlife species that attended the Wildlife Hospital of Universidad San Francisco de Quito (Ecuador) from April 2012 to January 2019.

Results: The microscopic evaluations of animals as potential reservoirs for vector-borne zoonotic blood parasites revealed the presence of Anaplasma spp., Babesia spp., Ehrlichia spp., Hepatozoon spp., microfilaria, Mycoplasma spp., and Trypanosoma spp. in previously unreported wildlife species. In addition, we performed a systematic review to understand the current knowledge gaps in the context of these findings.

Conclusion: Our data contribute to the knowledge of blood parasites in wildlife from Ecuador. Furthermore, the potential transmission of these parasites to humans and domestic animals, current anthropogenic environmental changes in the region, and the lack of information on this suggest the importance of our results and warrant further investigations on infectious diseases in animals and humans and their relationship with environmental health as key domains of the One Health concept.
\end{abstract}

Keywords: amazon basin, blood parasites, Ecuador, free-ranging wildlife, hemoparasites, one health, systematic review, vector-borne zoonotic.

\section{Introduction}

From an ecological perspective, a parasite lives in association with another organism [1]. Parasites that live in the host's blood are called blood parasites (hemoparasites), which include several species of the genera Anaplasma, Babesia, Ehrlichia, Haemoproteus, Hepatozoon, Leishmania, Leucocytozoon, Mycoplasma, Plasmodium, Schellackia, and Trypanosoma, among others [2-6]. Usually, hosts become infected through arthropod vectors such as fleas, flies, mosquitoes, or ticks [7]. Blood parasites are globally distributed and infect a wide variety of amphibians [8,9], reptiles [10], birds [11,12], and mammals, including humans [13].

Parasitism is considered by some scientists as a malevolent condition where parasites survive at some

Copyright: Diaz, et al. Open Access. This article is distributed under the terms of the Creative Commons Attribution 4.0 International License (http://creativecommons.org/licenses/by/4.0/), which permits unrestricted use, distribution, and reproduction in any medium, provided you give appropriate credit to the original author(s) and the source, provide a link to the Creative Commons license, and indicate if changes were made. The Creative Commons Public Domain Dedication waiver (http://creativecommons.org/ publicdomain/zero/1.0/) applies to the data made available in this article, unless otherwise stated. cost to host health status [14]. Some parasites have coevolved with their hosts, permitting prolonged interactions, and minimum parasite damage [15]. However, when these parasites are transmitted from their original hosts to humans (zoonotic transmission), the infection may produce damaging pathology, potentially leading to severe diseases and even death [16]. Thus, wildlife species are natural reservoirs of a wide range of zoonotic parasites and may serve as sentinel species for emerging diseases $[8,17]$. In this context, the One health paradigm gives the cornerstones of the relationship between wildlife and human health. This concept encompasses the provision of health for humans, animals, and environment through the interactions between all three pillars. To date, the One health triad application is being emphasized to control, prevent, and monitor infectious diseases [18]. Currently, increasing research efforts have been concentrated on selected blood parasites, mainly Leishmania spp., Plasmodium spp., and Trypanosoma spp. [7,18-21]. However, many vector-borne zoonotic hemoparasites from wildlife sources have been neglected; thus, information relating to their epidemiology and spillover related to human activity remains relatively uncharacterized [7,16-21]. 
In this study, we screened for blood parasites in blood smears from Ecuadorian free-ranging wildlife species admitted to the Wildlife Hospital at Universidad San Francisco de Quito, from April 2012 to January 2019. Furthermore, we complemented our findings with a systematic review of the literature investigating these parasites in wild animal species and their locations. The possible danger that the identified pathogens have in line with the One Health concept is also discussed, as some parasitic diseases are interconnected not only with animal health but also with human health through environmental relations [22].

\section{Materials and Methods \\ Ethical approval}

This study was conducted under the permit issued by Ecuador's Ministry of Environment (019-2018-IC-FAU-DNB/MAE) and authorized by the Animal Ethics Committee of Universidad San Francisco de Quito USFQ (2018-011).

\section{Study period and location}

Laboratory results reported in this study were compiled in February 2019 from animals admitted from April 2012 to January 2019. A database search for the systematic review was performed in June 2020. The study was performed in the Wildlife Hospital of Universidad San Francisco de Quito (Quito, Ecuador).

\section{Specimen selection/collection/identification}

The laboratory results of blood samples belonged to free-ranging wildlife species from Ecuador were compiled. All animals were admitted from April 2012 to January 2019 to the Wildlife Hospital of Universidad San Francisco de Quito and sample collection was performed exclusively for infectious disease diagnostics. Samples were analyzed by Lab-Vet (permit Ref. No.: AGR-AGROCALIDAD/CDL2018-000052-OF), using published and standard laboratory methods based on blood smear visualization by light microscopy using a 40X magnifying lenses.

\section{Literature review}

\section{PubMed}

(https://www.ncbi.nlm.nih.gov/ pubmed), Scopus (https://www.scopus.com), and Web of Science (https://www.webofknowledge.com) databases were accessed and searched for published reports that match to our findings, search was performed on June 16, 2020. Search terms allowed us to retrieve original studies reporting Anaplasma, Babesia, Ehrlichia, Hepatozoon, microfilaria, Mycoplasma, and Trypanosoma in wild animal species. Search terms were used in all three databases to match the following combination of terms: (1) Anaplasma: Anaplasma AND ((Lagothrix AND lagotricha) OR (Saguinus AND fuscicollis) OR (Cebus AND albifrons)); (2) Babesia: Babesia AND ((Mazama AND rufina) OR (Lagothrix AND lagotricha) OR (Saguinus AND fuscicollis)); (3) Ehrilichia: Ehrilichia AND (Mazama AND rufina); (4) Hepatozoon: Hepatozoon AND (Melanosuchus niger OR Caiman crocodilus OR Boa constrictor); (5) Microfilaria: Microfilaria AND (M. niger OR Lagothrix lagotricha OR Nasua nasua); (6) Mycoplasma: ((Mycoplasma OR Haemobartonella) AND (N. nasua OR Panthera onca OR Puma concolor OR Leopardus tigrinus OR Leopardus pardalis OR Puma yagouaroundi OR Herpailurus yagouaroundi OR Potos flavus OR Lagothrix lagotricha OR Alouatta palliata OR Alouatta seniculus OR Cebus albifrons OR Sapajus apella OR Saimiri sciureus OR Saguinus fuscicollis OR Cebuella pygmaea OR C ebuella pygmaea OR Odocoileus virginianus OR Pudu mephistophiles OR Mazama rufina OR Choloepus didactylus OR Choloepus hoffmanni)); and (7) Trypanosoma: Trypanosoma AND (Choloepus AND hoffmanni). Searches were performed in July 2020 without publication year restrictions. Records in English, Portuguese, and Spanish were included in the study. The following were excluded from the study: (i) Studies that did not report the gender of blood parasites in animal species similar to this study, (ii) studies reporting vector-borne infections in animals other than the ones that we are reporting in this study (Table-1), (iii) studies conducted in laboratory animals or non-natural infections, (iv) duplicated titles or articles reporting results of other studies (ei. Reviews, not original research), and (v) studies that search for the parasites but do not find evidence of infection (negative reports) (Supplementary data can be available from the corresponding author). The country, publication year, blood parasite species, infected animal species, and diagnostic techniques (Supplementary data can be available from the corresponding author) were recorded for each manuscript.

\section{Results}

\section{Hemoparasites in blood samples from free-ranging wildlife species}

From April 2012 to January 2019, 290 free-ranging wildlife animals attended our veterinary facility, including 209 mammals, 52 reptiles, and 29 birds (Supplementary data can be available from the corresponding author). Blood parasites were detected in $97(33.45 \%)$ animals, of which 87 were mammals and ten were reptiles. No positivity was identified in birds.

Anaplasma spp. was registered in four samples from three nonhuman primate species: Two Whitefronted capuchin (C. albifrons) and one Brown woolly monkey (L. lagotricha) demonstrated coinfection with Mycoplasma spp. and also one Brown-mantled tamarin (S. fuscicollis) (Table-1). Babesia spp. was found in three mammal species: One Brown woolly monkey, one Brown-mantled tamarin, and one Little red brocket (M. rufina) that showed coinfection with Mycoplasma spp. and Ehrlichia spp., respectively. We also identified another Little red brocket infected with Ehrlichia spp. Mycoplasma spp. was the most frequent hemoparasite and was identified in $80(91.95 \%)$ of the positive samples from 20 different mammal species (Table-1). Mycoplasma was followed by Hepatozoon 


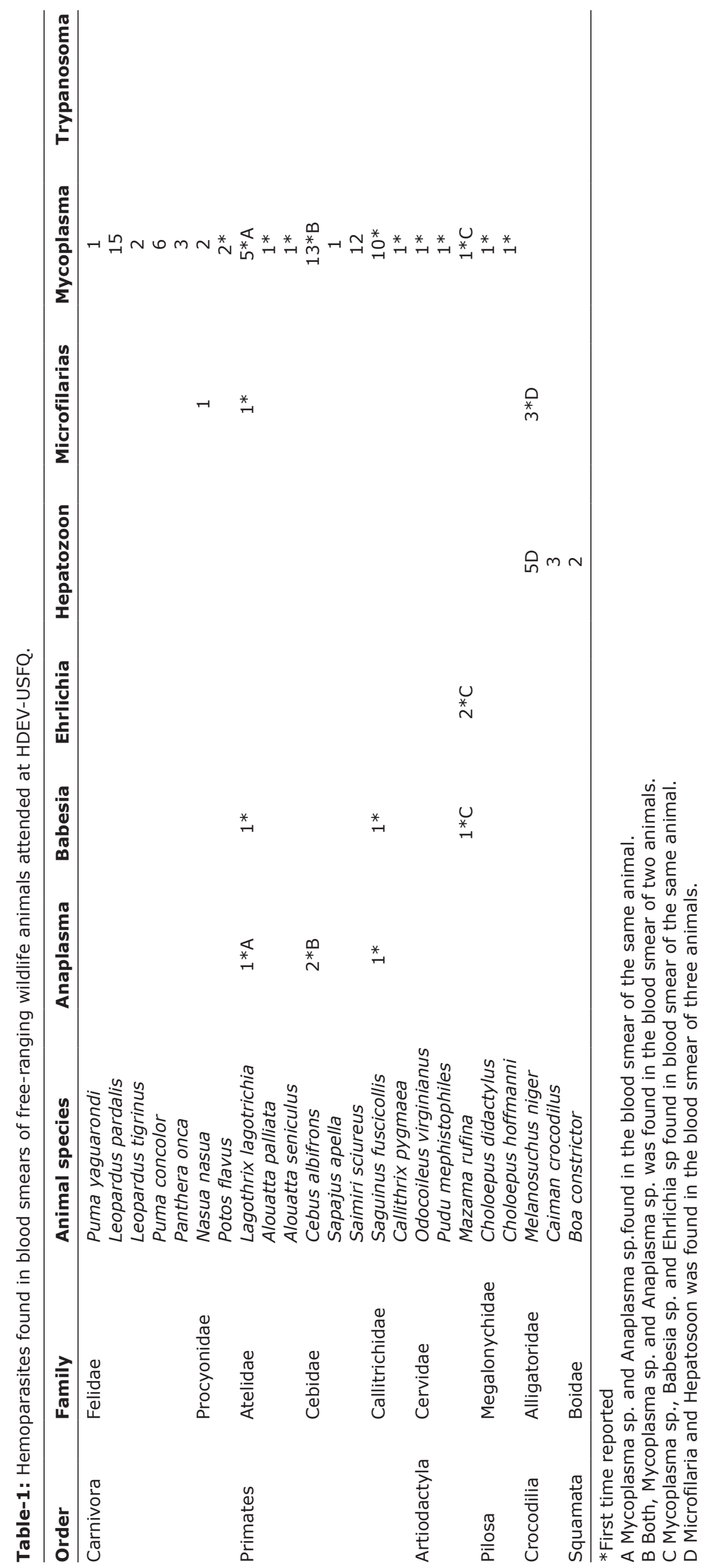


spp. and was found in samples from ten reptiles (five Black caiman - $M$. niger, two snakes $B$. constrictor, and three Spectacled caimans - C. crocodilus). Three Black caiman showed coinfection with microfilariae. Microfilaria was also found in a South American coati (N. nasua) and a Brown woolly monkey. Finally, we identified one Hoffmann's two-toed sloth $(C$. hoffmanni) positive for Trypanosoma spp. (Table-1).

\section{Literature searches to investigate hemoparasites in animal species reported in this study}

In total, 41 reports matched the hemoparasite findings in the 23 free-ranging wildlife species reported here (Supplementary data can be available from the corresponding author). Twelve studies reported more than one parasite or infected wild animal [23-34]. The search yielded studies from 1979 to 2019 , with Brazil having the most studies $(\mathrm{n}=26)$. The remaining studies were conducted in the USA $(n=4)$, French Guiana $(n=4)$, Colombia $(n=2)$, Mexico $(n=2)$, Costa Rica $(n=2)$, and Peru $(n=1)$.

Our literature review identified 16 Hepatozoon studies that matched our reptile findings. Reports of Hepatozoon fusifex, Hepatozoon terzii, and Hepatozoon cuestensis were identified for B. constrictor and Hepatozoon caimani for C. crocodilus and $M$. niger. The most common technique used to detect these parasites was the microscopic observation of blood smears. Electron microscopy and molecular detection (followed by sequencing) techniques were also used to identify Hepatozoon species [34-36]. For Mycoplasma, various species were previously reported in nine out of the 21 searched mammal species (Table-2) [3,23,25-34,37-56]. Mycoplasma spp. detection and identification were primarily conducted using polymerase chain reaction (PCR) and sequencing. For Trypanosoma species, Trypanosoma leeuwenhoek and
Trypanosoma rangeli were isolated and identified in C. hoffmanni using blood smear microscopic observations, histopathology, parasite culture, and PCR. Finally, microfilariae were previously observed in $N$. nasua and M. niger blood smears. Microfilaria in samples from N. nasua was identified as Dirofilaria repens, Dirofilaria immitis, Acanthocheilonema reconditum, Mansonella spp., and Brugia spp.

Our literature search did not identify Hepatozoon spp. in M. niger or Mycoplasma spp. in P. flavus, $L$. lagotricha, A. palliata, A. seniculus, C. albifrons, P. mephistophiles, S. fuscicollis, C. pygmaea, $M$. rufina, $C$. didactylus, or $C$. hoffmanni. In addition, no publications reported the presence of Babesia spp. in M. rufina, L. lagotricha, or S. fuscicollis or Ehrlichia in M. rufina.

\section{Discussion}

The detection of vector-borne blood parasitized wildlife species may provide valuable information on the transmission cycles of pathogens in nature. Knowing the potential parasite reservoirs could inform authorities to implement preventative measures to reduce the risk to wildlife, domestic animal, and human health [57]. From a public health perspective, this approach should be of particular relevance to environments with high animal diversity, where habitat fragmentation has affected the abundance and distribution of vectors and reservoirs involved in the transmission cycle of zoonotic parasites [58].

This study reported vector-borne zoonotic blood parasites in several wild mammal and reptile species from Ecuador. The findings were complemented by data from a systematic review where we searched studies of hemoparasites that infect the wild species identified in our work. For the first time, we report

Table-2: Hemoparasites that have been previously reported in free-ranging wildlife animals.

\begin{tabular}{ll}
\hline Hemoparasite & Animal \\
\hline Hepatozoon spp. [3,34,37-44] & Caiman crocodilus, Boa constrictor \\
Hepatozoon caimani [45,46] & Caiman crocodilus \\
Hepatozoon fusifex [47] & Boa constrictor \\
Hepatozoon terzii [48] & Boa constrictor \\
Hepatozoon cuestensi [49] & Boa constrictor \\
Mycoplasma spp. [26, 50] & Puma concolor, Odocoileus virginianus \\
Mycoplasma haemocanis [28] & Nasua nasua \\
Mycoplasma haemofelis [23,25, 32-33,51] & Nasua nasua, Pantera onca, Puma concolor, Leopardus tigrinus \\
Mycoplasma haemocanis/Mycoplasma haemofelis [28,32] Leopardus pardalis \\
Candidatus Mycoplasma turicensis [23,32,51] & Nasua nasua, Pantera onca, Leopardus pardalis \\
Candidatus Mycoplasma haemominutum & Pantera onca, Puma concolor, Leopardus tigrinus, Leopardus \\
[23,25,26,29-32] & pardalis \\
Candidatus Mycoplasma haemomacaque [27] & Sapajus apella \\
Candidatus Mycoplasma kahaneii [27,30] & Saimiri sciureus \\
Trypanosoma leeuwenhoek [52] & Choloepus hoffmanni \\
Trypanosoma rangeli [53,54] & Choloepus hoffmanni \\
Dirofilaria repens [55] & Nasua nasua \\
Dirofilaria immitis[55] & Nasua nasua \\
Acanthocheilonema reconditum [55] & Nasua nasua \\
Mansonella spp. [55] & Nasua nasua \\
Brugia spp. [55] & Nasua nasua \\
Non identified mirofilaria species [56] & Melanosuchus niger \\
\hline
\end{tabular}


the occurrence of Anaplasma, Babesia, Ehrlichia, Hepatozoon, and Mycoplasma in various wild animal species. These data suggest knowledge gaps of infectious diseases circulating in wildlife from different ecosystems in our region.

All hemoparasites identified here could infect numerous animal species, including humans, and may be biologically or mechanically transmitted by arthropods. Anaplasmosis and ehrlichioses are two tick-borne infectious diseases and are well known in veterinary medicine circles and were recently shown to cause mild, moderate, and severe disease in humans [59]. Both bacteria are obligate intracellular pathogens vectored by ticks, which serve as vectors for vertebrate hosts $[60,61]$. Babesiosis is an emerging zoonotic disease caused by tick-borne apicomplexan protozoa of the genus Babesia [62]. This pathogen infects a wide range of animals, with wildlife species being the principal reservoir hosts for zoonotic Babesia species [63]. Hepatozoon spp. is intraerythrocytic tick-borne protozoa; infections occur when an infected invertebrate host is ingested by a vertebrate host. Infection with Hepatozoon spp. can affect birds mammals and reptiles and can produce mild to severe disease including symptoms such as anorexia, weight loss, fever, and polyuria, or remain asymptomatic [64-66]. Humans infected with Hepatozoon have been reported [67], suggesting a possible but rare infection incidence. Filarial nematodes are vector-borne worms that release microfilariae into the host blood; these pathogens are considered to be a threat for animal and human health [68]. Most have adapted to the transmission through hematophagous arthropods [69] and can be found in surgical tissue biopsy specimens or removed intact from superficial sites from infected animals [70]. Globally, Mycoplasma spp. represent emerging pathogens in animals and humans, with wildlife animals being important bacterial reservoirs [71,72]. These organisms are epicellular erythrocytic pathogens, transmitted by blood-feeding arthropod vectors $[73,74]$ and causing asymptomatic to mild and severe disease in a wide variety of mammalian species [75]. Finally, trypanosomes, the most common hemoparasites in the world, are transmitted by hematophagous invertebrate vectors [76]. They infect humans and domestic and wild animal species, often causing chronic and fatal diseases [77].

The most common hemoparasite observed in this study was Mycoplasma, infecting a variety of wildlife species from Artiodactyla, Carnivora, Crocodilia, Pilosa, Primates, and Squamata orders (Table-1). Multiple Mycoplasma species have been reported in Nasua spp., including coinfection with Trypanosoma cruzi in Nasua narica from Costa Rica [78]. We also observed this microorganism in Odocoileus virginuanus. About Mycoplasma, the two species that commonly infect cervids are $M$. ovis and $M$. haemocervae, and we were able to identified a report that describes a genetically closely related species to $M$ ovis infecting
O. virginuanus [79]. In addition, Mycoplasma infection in free-ranging felids was higher than in wild felids from zoos [26]. Several studies described Mycoplasma circulation among domestic cats and free-ranging felids $[26,80,81]$. Here, we reported for the first time the presence of Mycoplasma in 27 wild felids from Ecuador. These felids belonged to five different species, which are all free-ranging animals. Felids are important top predators; thus, the identification of hemoparasites infections may suggest these animals are bioaccumulating pathogens from prey species [82]. This may be why we did not find Mycoplasma in $M$. niger. Likewise, Mycoplasma reports were not identified for $A$. palliata and $A$. seniculus. However, this was expected as previous studies have reported the presence of Candidatus Mycoplasma kahane in Alouatta caraya and Sapajus flavius [24,74]. Our systematic review found that Mycoplasma was not reported in species such as Choloepus spp., Lagothrix lagotricha, Mazama rufina, P. flavus. and P. mephistophiles among others, agreed with our laboratory findings. This information identified knowledge gaps in the prevalence and dynamics of Mycoplasma species in wildlife animals.

Despite Trypanosoma spp. being one of the most common hemoparasite genera in wildlife [83-86] and its repeated identification in multiple sloth species $[3,54,87-89]$, we identified it only in $C$. hoffmanni. For microfilaria species, they were previously reported in $M$. niger and $N$. nasua. In the latter, reports of $D$. repens, $D$. immitis, A. reconditum, Mansonella spp., and Brugia spp. suggested its importance as a reservoir, while the filaria infecting $M$. niger remains known [55]. Here, we reported for the first time the presence of microfilaria in L. lagotricha. However, further studies are required to identify filaria diversity infecting other wildlife species, including $M$. niger and L. lagotricha.

Hepatozoon mainly infects reptiles and, to a lesser extent, mammals $[3,90]$. We observed this genus in the reptiles, C. crocodilus, B. constrictor, and M. niger. Interestingly, only $H$. caimani was identified in Caiman spp. This result is notoriously contrasting with the reports of a high diversity of Hepatozoon species (H. fusifex, H. terzii, and H. cuestensis) that could infect B. constrictor [43,91-93]. We also reported the presence of Ehrlichia in M. rufina, even though we were unable to identify previous reports of this infection. However, Ehrlichia studies exist for other deer species [94]. Likewise, we did not find reports of Anaplasma in $S$. fuscicollis, C. albifrons, and L. lagotricha nor reports of Babesia in S. fuscicollis, L. lagotricha, and M. rufina, although these two hemoparasites have been reported in other nonhuman primates and ruminants [95-97]. Therefore, these data contribute to the distribution knowledge of these hemoparasites.

The analytical methodology used in our study was based on blood smear visualization using light microscopy, a method traditionally used for blood 
parasite diagnostics in veterinary medicine [98]. Although microscopic diagnostic sensitivity and specificity for this method are generally lower than PCR [71], it generates fewer false positives, which is often a major concern in large-scale PCR studies $[99,100]$. However, the microscopic identification of some blood parasites, for example, Babesia spp. [101], Hepatozoon spp. [102], or Microfilaria spp. [68], remains the "gold standard" diagnostic tool. Therefore, optical microscopy could be a simple and low-cost method for determining hemoparasite prevalence in wildlife [103-105]. We readily acknowledge that the results from this research may be underestimated due to our favoring only microscopic techniques. Therefore, further studies using combined morphological and molecular analyses are required to provide more precise identifications of blood parasites in wildlife [95,103-104].

An interesting finding from this study was that most wildlife species (22 out of 23), where zoonotic blood parasites were detected, were distributed in the Amazon Basin: Alouatta. seniculus [105], B. constrictor [106], $C$. crocodilus [107], C. pygmaea [108], C. albifrons [109], Cebus macrocephalus [110], C. didactylus [111], C. hoffmanni [112], L. lagotricha [113], Leopardus pardalis [114], L. tigrinus [115], M. rufina [116], M. niger [117], N. nasua [118], O. virginianus [119], $P$. onca [120], P. flavus [121], P. mephistophiles [122], $P$. concolor [123], P. yagouaroundi [124], S. fuscicollis [125], and S. sciureus [126]. Only A. palliata is not distributed in the Amazon basin, it lives in the Choco Tropical Rain Forest, and in the deciduous and piemontan forest of the Western Cordillera of the Ecuadorian Andes [127].

The Amazon Basin comprises many of the most diverse global ecosystems across seven countries, namely, Bolivia, Brazil, Colombia, Ecuador, Guyana, Peru, and Venezuela [128]. These complex ecosystems contain natural foci of vector-borne human parasitic diseases. However, disease dynamics have been greatly affected due to deforestation and climate change $[129,130]$. Vector-borne diseases are particularly sensitive to climate warming, as arthropod vector development rates, geographical distribution, and transmission dynamics are altered [131,132]. Along with increased global temperatures, anthropogenic factors, such as increased urbanization, agriculture, and livestock, are invading wildlife habitats, with increased interactions between humans, domestic, and wild animals $[133,134]$. These changes in wild ecosystems create new opportunities for vector establishment or increases in existing populations [7,20,101,135]. Specifically, Ecuador has suffered the highest deforestation rate in South America [136], with evidence showing that $46 \%$ of South Ecuador's original forest cover had been converted by 2008 into pastures and other anthropogenic land covers [137]. Furthermore, projected models for future climate change scenarios in Ecuador have demonstrated potential shifts in mosquito distribution, that could lead to an increase of vector-borne infectious diseases [138].

Our systematic review revealed a dearth of publications on selected hemoparasites in the animal species we identified from the Amazon Basin. Specifically, no publications emanated from Bolivia, Ecuador, and Venezuela, whereas most of the research came from Brazil. Therefore, an important vector-borne zoonotic blood parasitology research gap exists in these regions. For these reasons, research efforts are required in these regions where current environmental changes could lead to new epidemiological patterns in vector-borne disease, generating negative impacts on wildlife, domestic animals, and human health. Indeed, pathogen transmission from a vertebrate animal to a human (zoonotic spillover) represents a global but poorly understood public health issue [134]. Thus, a better understanding of the evolution and ecology of zoonotic blood parasites is crucial to determine the foci of possible emerging infectious diseases and to prevent the outbreak of diseases $[139,133]$. Therefore, as other authors have indicated $[38,129]$, epidemiological surveillance is required to address vector-borne zoonotic blood parasites in the Amazon Basin and other highly diverse ecosystems. In addition, as interfaces between wildlife, domestic animals, and human populations interact and become more complex, more interdisciplinary collaborations will be required to prevent disease transmission at these junctures [140,141]. The only way authorities and policymakers will make informed decisions and prioritize action issues is to foster projects framed under the one health initiative, contributing to public health improvement, wildlife conservation, and livestock sustainability through this holistic strategy [142].

\section{Conclusion}

We described vector-borne zoonotic blood parasite diversity in wildlife species from Ecuador and highlighted the lack of information in the region. Indeed, zoonotic spillover is a poorly understood public health issue; thus, our work emphasizes how research can determine if infected wildlife are important reservoirs of hemoparasites distinct to the common Leishmania spp., Plasmodium spp., and Trypanosoma spp. In addition, the fact that all the blood parasites identified in this work are transmitted by arthropod vectors suggests that their ecology and distribution may be affected by habitat fragmentation and climate change. Our data add relevant information to the literature on infectious diseases in wildlife and spotlights the need to understand diseases and its consequences in animal and human health within ecosystem conservation and dynamics, which are the pillars of the one health framework.

\section{Authors' Contributions}

ED: Conceptualization, methodology, writing - original draft, review, and editing. $\mathrm{AH}$, 
CV, GD: Methodology, data compilation. VAB: Conceptualization, methodology, writing - review and editing, and supervision. All authors have read and approved the final manuscript.

\section{Acknowledgments}

We are grateful to Universidad San Francisco de Quito, Ecuador (COCIBA and Veterinary School Grants - Hubi 7699), and the staff of TUERI for providing necessary support. Publication of this article was funded by Universidad San Francisco de Quito, Ecuador, under Research Publication Fund.

\section{Competing Interests} interests.

The authors declare that they have no competing

\section{Publisher's Note}

Veterinary World remains neutral with regard to jurisdictional claims in published institutional affiliation.

\section{References}

1. Gómez-Arreaza, A., Haenni, A.L., Dunia, I. and Avilan, L. (2016) Viruses of parasites as actors in the parasite-host relationship: A "Ménage à Trois". Acta Trop., 166: 126-132.

2. Davies, A.J. and Johnston, M.R. (2000) The biology of some intraerythrocytic parasites of fishes, amphibia and reptiles. Adv. Parasitol., 45: 1-107.

3. de Thoisy, B., Michel, J.C., Vogel, I. and Vié, J.C. (2000) A survey of hemoparasite infections in free-ranging mammals and reptiles in French Guiana. J. Parasitol., 86(5): 1035-1040.

4. Scheuerlein, A. and Ricklefs, R.E. (2004) Prevalence of blood parasites in European passeriform birds. Proc. R. Soc. B Biol. Sci., 271(1546): 1363-1370.

5. Quillfeldt, P., Arriero, E., Martínez, J., Masello, J.F. and Merino, S. (2011) Prevalence of blood parasites in seabirds-a review. Front. Zool., 8(1): 26.

6. Halla, U., Ursula, H., Korbel, R., Rüdiger, K., Mutschmann, F., Frank, M., Rinder, M. and Monika, R. (2014) Blood parasites in reptiles imported to Germany. Parasitol. Res., 113(12): 4587-4599.

7. Colwell, D.D., Dantas-Torres, F. and Otranto, D. (2011) Vector-borne parasitic zoonoses: Emerging scenarios and new perspectives. Vet. Parasitol., 182(1): 14-21.

8. McKenzie, V.J. and Starks, H.A. (2008) Blood parasites of two Costa Rican amphibians with comments on detection and microfilaria density associated with adult filarial worm intensity. J. Parasitol., 94(4): 824-829.

9. Netherlands, E.C., Cook, C.A., Kruger, D.J.D., du Preez, L.H. and Smit, N.J. (2015) Biodiversity of frog haemoparasites from sub-tropical northern KwaZulu-Natal, South Africa. Int. J. Parasitol. Parasites Wildl., 4(1): 135-141.

10. Haklová, B., Majláthová, V., Majláth, I., Harris, D.J., Petrilla, V., Litschka-Koen, T., Oros, M. and Pet'ko, B. (2014) Phylogenetic relationship of Hepatozoon blood parasites found in snakes from Africa, America and Asia. Parasitology, 141(3): 389-398.

11. Reullier, J., Pérez-Tris, J., Bensch, S. and Secondi, J. (2006) Diversity, distribution and exchange of blood parasites meeting at an avian moving contact zone. Mol. Ecol., 15(3): 753-763.

12. Vanstreels, R.E.T., Braga, É.M. and Catão-Dias, J.L. (2016) Blood parasites of penguins: A critical review. Parasitology, 143(8): 931-956.

13. Coura, J.R. and Viñas, P.A. (2010) Chagas disease: A new worldwide challenge. Nature, 465(7301): S6-7.

14. McKay, D.M. (2006) The beneficial helminth parasite? Parasitology, 132(1): 1-12.

15. Kutzer, M. A. M. and Armitage, S. A. O. (2016) Maximizing fitness in the face of parasites: a review of host tolerance. Zoology., 119(4): 281-289.

16. Falcone, F. and Pritchard, D. (2005) Parasite role reversal: Worms on trial. Trends Parasitol., 21(4): 157-160.

17. Polley, L. (2005) Navigating parasite webs and parasite flow: Emerging and re-emerging parasitic zoonoses of wildlife origin. Int. J. Parasitol., 35(11-12): 1279-1294.

18. Thompson, R.C.A. (2013) Parasite zoonoses and wildlife: One Health, spillover and human activity. Int. J. Parasitol., 43(12-13): 1079-1088.

19. Torgerson, P.R. and Macpherson, C.N.L. (2011) The socioeconomic burden of parasitic zoonoses: Global trends. Vet. Parasitol., 182(1): 79-95.

20. Chhabra, M. and Muraleedharan, K. (2016) Parasitic zoonoses and role of wildlife: An overview. Vet. Res. Int., 4(1): 1-11.

21. Schurer, J.M., Mosites, E., Li, C., Meschke, S. and Rabinowitz, P. (2016) Community-based surveillance of zoonotic parasites in a one health world: A systematic review. One Health Amst. Neth., 2: 166-174.

22. Degeling, C., Lederman, Z., Rock, M. (2016) Culling and the Common Good: Re-evaluating Harms and Benefits under the One Health Paradigm. Public Health Ethics, 9 (3): 244-254

23. Furtado, M.M., Taniwaki, S.A., Metzger, B., O’Dwyer, L.H., Paduan, K.D.S., de Almeida Jácomo, A.T., de Oliveira Porfírio, G.E., Silveira, L., Sollmann, R., Tôrres, N.M. and Ferreira Neto, J.S. (2018) First detection of feline hemoplasmas in free-ranging jaguars (Panthera onca). Vet. Microbiol., 214: 75-80.

24. Fernandes de Melo, C.M., Daneze, E.R., Mendes, N.S., de Souza Ramos, I.A., Morales-Donoso, J.A., Fernandes, S.J., Machado, R.Z., André, M.R. and da Rosa Sobreira, M.F. (2019) Genetic diversity and hematological and biochemical alterations in Alouatta primates naturally infected with hemoplasmas in Brazil. Comp. Immunol. Microbiol. Infect. Dis., 63: 104-111.

25. André, M.R., Adania, C.H., Allegretti, S.M. and Machado, R.Z. (2011) Hemoplasmas in wild canids and felids in Brazil. J. Zoo Wildl. Med., 42(2): 342-347.

26. Gilbertson, M.L.J., Carver, S., VandeWoude, S., Crooks, K.R., Lappin, M.R. and Craft, M.E. (2016) Is pathogen exposure spatially autocorrelated? Patterns of pathogens in puma (Puma concolor) and bobcat (Lynx rufus). Ecosphere, 7(11): e01558.

27. Bonato, L., Figueiredo, M.A.P., Gonçalves, L.R., Machado, R.Z. and André, M.R. (2015) Occurrence and molecular characterization of Bartonella spp. and hemoplasmas in neotropical primates from Brazilian Amazon. Comp. Immunol. Microbiol. Infect. Dis., 42: 15-20.

28. De Sousa, K.C.M., Herrera, H.M., Secato, C.T., do Vale Oliveira, A., Santos, F.M., Rocha, F.L., Barreto, W.T.G., Macedo, G.C., de Andrade Pinto, P.C.E., Machado, R.Z., Costa, M.T., Andre, M.R. (2017) Occurrence and molecular characterization of hemoplasmas in domestic dogs and wild mammals in a Brazilian wetland. Act Trop. 171:172-181

29. Ribeiro, C.M., Calistro de Matos, A., Richini-Pereira, V. B., Lucheis, S.B., Azzolini, F., Sipp, P.J., Lima, P.P., Katagiri, S., Vidotto, O. (2017) Occurrence and phylogenetic analysis of 'Candidatus Mycoplasma haemominutum' in wild felines from Paraná, Brazil. Semina: Ciencias Agrarias., 38(4): 1

30. Neimark, H., Barnaud, A., Gounod, P., Michel, J., Contamin, H. (2002) The putative haemobartonella that influences Plasmodium falciparum parasitaemia in squirrel monkeys is a haemotrophic mycoplasma. Microbes Infect., 4(7):693-8.

31. Kellner, A., Carver, S., Scorza, V., McFee, C.D., Lappin, M., Crooks, K., VandeWoude, S., Antolin, M. 
(2018) Transmission pathways and spillover of an erythrocytic bacterial pathogen from domestic cats to wild felids. Ecol Evol., 8(19):9779-9792.

32. Willi, B., Filoni, C., Catão-Dias, J., Cattori, V., Meli, M., Vargas, A., Martínez, F., Roelke, M., Ryser-Degiorgis, M.P., Leutenegger, C., Lutz, H. and Hofmann-Lehmann, R. (2007) Worldwide occurrence of feline hemoplasma infections in wild felid species. J. Clin. Microbiol., 45(4): 1159-1166.

33. Sanchioli, R. (2015) Micoplasmose hemotrópica felina em onça-pintada (Panthera onca): Relato de caso. Biotemas, 28(2): 153

34. Paperna, I. and Lainson, R. (2003) Ultrastructural studies on the sporogony of Hepatozoon spp. in Culex quinquefasciatus say, 1823 fed on infected Caiman crocodilus and Boa constrictor from northern Brazil. Parasitology, 127(2): 147-154.

35. Modrý, D., Beck, R., Hrazdilová, K., Baneth, G. (2017) A Review of Methods for Detection of Hepatozoon Infection in Carnivores and Arthropod Vectors», Vector-Borne Zoonotic Dis., 17(1): 66-72.

36. de Sousa, K.C.M., Fernandes, M.P., Herrera, H.M., Benevenute, J.L., Santos, F.M., Rocha, F.L., Barreto, W.T.G., Macedo, G.C., Campos, J.B., Martins, T.F., de Andrade Pinto, P.C.E., Battesti, D.B., Piranda, E.M., Cançado, P.H.D., Machado, R.Z. and André, M.R. (2017) Molecular detection of Hepatozoon spp. in domestic dogs and wild mammals in southern Pantanal, Brazil with implications in the transmission route. Vet. Parasitol., 237: 37-46.

37. Calil, P., Puorto, G., Dunn, J., Chagas, C. and Ramos, P. (2019) Molecular and morphological characterization of Hepatozoon spp. in Brazilian snakes. Amphib. Reptil., 40(3): 1113.

38. Soares, H.S., Marcili, A., Barbieri, A.R.M., Minervino, A.H.H., Moreira, T.R., Gennari, S.M. and Labruna, M.B. (2017) Novel piroplasmid and Hepatozoon organisms infecting the wildlife of two regions of the Brazilian Amazon. Int. J. Parasitol. Parasites Wildl., 6(2): 115-121.

39. Lopes, F., Azevedo, S.S., Dantas, L.A.B., Freitas, C., Batista, C.S.A. and Azevedo, A. (2010) Occurrence of Hepatozoon spp. (Apicomplexa, Hepatozoidae) in captive Boa constrictor snakes in the semi-arid of Rio Grande do Norte State, Northeastern Brazil. Arq. Bras. Med. Vet. E. Zootec., 62(5): 1285-1287.

40. O’Dwyer, L.H., Moço, T.C., Barrella, T.H., Vilela, F.C. and Silva, R.J. (2003) Prevalence of Hepatozoon spp. (Apicomplexa, Hepatozoidae) among recently captured Brazilian snakes. Arq. Bras. Med. Vet. E. Zootec., 55(3): 309-314.

41. Machado, C.C., Silva, L.F.N., Ramos, P.R.R. and Takahira, R.K. (2006) Seasonal influence on hematologic values and hemoglobin electrophoresis in Brazilian boa constrictor amarali. J. Zoo Wildl. Med., 37(4): 487-491.

42. Moço, T.C. (2008) Hepatozoon spp. (Hepatozoidae) prevalence in snakes: Morphological, morphometrical and molecular characterization in Crotalus durissus terrificus (Viperidae) naturally infected. J. Venom. Anim. Toxins Trop. Dis., 14(3): 554-554.

43. Zamudio Zuluaga, N. and Ramírez Monroy, M. (2007) Presencia de Hepatozoon spp. En serpientes del centro de atención y valoración de fauna silvestre (CAV) del área metropolitana del valle de Aburra, Barbosa-Antioquia. CES Med. Vet. Zootec., 2(2): 33-36.

44. García-Márquez, L., Rodríguez-Vázquez, A., LeónRègagnon, V., Osorio-Sarabia, D. and Garcia Prieto, L. (2019) Parasites of Boa constrictor (Squamata: Boidae) captive in Colima, Mexico and their pathological effects. Rev. Mex. Biodivers., 90(2021): 5622-9164.

45. Lainson, R., Paperna, I. and Naiff, R.D. (2003) Development of Hepatozoon caimani (Carini, 1909) Pess a, De Biasi and De Souza, 1972 in the Caiman Caiman C. crocodilus, the frog Rana catesbeiana and the mosquito Culex fatigans.
Mem. Inst. Oswaldo Cruz, 98(1): 103-113.

46. Rojas, G., Alvis, R., Pino, J. and Shiga, B. (2011) Presencia de Hepatozoon caimani (Apicomplexa: Hepatozoidae) en el caimán blanco Caiman crocodilus (Linneus 1758) en un zoológico de Lima, Perú. Rev. Investig. Vet. Perú., 22(1): 56-60.

47. Ball, G.H., Chao, J. and Telford, S.R. (1969) Hepatozoon fusifex spp. N., a mehogregarine from boa constrictor producing marked morphological changes in infected erythrocytes. J. Parasitol., 55(4): 800-813.

48. de Vieira Santos, M.M., O’Dwyer, L.H. and da Silva, R.J. (2005) Seasonal variation of Hepatozoon spp. (Apicomplexa, Hepatozoidae) parasitemia from Boa constrictor amarali (Serpentes, Boidae) and Hydrodynastes gigas (Serpentes, Colubridae). Parasitol. Res., 97(2): 94-97.

49. Úngari, L.P., Santos, A.L.Q., O’Dwyer, L.H., da Silva, M.R.L., Rodrigues Santos, T.C., da Cunha, M.J.R., de Melo Costa Pinto, R. and Cury, M.C. (2018) Molecular characterization and identification of Hepatozoon species Miller, 1908 (Apicomplexa: Adeleina: Hepatozoidae) in captive snakes from Brazil. Parasitol. Res., 117(12): 3857-3865.

50. Maggi, R.G., Chitwood, M.C., Kennedy-Stoskopf, S. and DePerno, C.S. (2013) Novel hemotropic Mycoplasma species in white-tailed deer (Odocoileus virginianus). Comp. Immunol. Microbiol. Infect. Dis., 36(6): 607-611.

51. Cubilla, M.P., Santos, L.C., de Moraes, W., Cubas, Z.S., Leutenegger, C.M., Estrada, M., Lindsay, L.L., Trindade, E.S., Franco, C.R.C., Vieira, R.F.C., Biondo, A.W. and Sykes, J.E. (2017) Microscopic and molecular identification of hemotropic mycoplasmas in South American coatis (Nasua nasua). Comp. Immunol. Microbiol. Infect. Dis., 53: $19-25$.

52. Travi, B.L., Zea, A. and D'Alessandro, A. (1989) Trypanosoma (Herpetosoma) leeuwenhoeki in Choloepus hoffmanni and Didelphis marsupialis of the Pacific Coast of Colombia. J. Parasitol., 75(2): 218-224.

53. Zeledón, R., Ponce, C. and Murillo, J. (1979) Leishmania herreri spp. N. From sloths and sandflies of Costa Rica. $J$. Parasitol., 65(2): 275-279.

54. Salazar-Antón, F., Urrea, D.A., Guhl, F., Arévalo, C., Azofeifa, G., Urbina, A., Blandón-Naranjo, M., Sousa, O.E., Zeledón, R. and Vallejo, G.A. (2009) Trypanosoma rangeli genotypes association with Rhodnius prolixus and $\mathrm{R}$. pallescens allopatric distribution in Central America. Infect. Genet. Evol., 9(6): 1306-1310.

55. Moraes, M.F.D., da Silva, M.X., Magalhães-Matos, P.C., Alexandre de Albuquerque, A.C., Tebaldi, J.H., Mathias, L.A. and Lux Hoppe, E.G. (2017) Filarial nematodes with zoonotic potential in ring-tailed coatis (Nasua nasua Linnaeus, 1766, Carnivora: Procyonidae) and domestic dogs from Iguaçu national park, Brazil. Vet. Parasitol. Reg. Stud. Rep., 8: 1-9.

56. Oliveira, A.T., Santos, M.Q.C., Pantoja-Lima, J., Machado, M.R.F., Lemos, J.R.G., Tavares-Dias, M., Aride, P.H.R., Oliveira, A.T., Santos, M.Q.C., PantojaLima, J., Machado, M.R.F., Lemos, J.R.G., TavaresDias, M. and Aride, P.H.R. (2017) First record of microfilaria in the blood of black caiman Melanosuchus niger (Crocodylia: Alligatoridae) specimens from the Amazon River basin. Braz. J. Biol., 77(4): 895-897.

57. Gortázar, C., Ferroglio, E., Höfle, U., Frölich, K. and Vicente, J. (2007) Diseases shared between wildlife and livestock: A European perspective. Eur. J. Wildl. Res., 53(4): 241.

58. Woodford, M.H. (2008) Veterinary aspects of ecological monitoring: The natural history of emerging infectious diseases of humans, domestic animals and wildlife. Trop. Anim. Health Prod., 41(7): 1023

59. Doudier, B., Olano, J., Parola, P. and Brouqui, P. (2010) Factors contributing to emergence of Ehrlichia and Anaplasma spp. As human pathogens. Vet. Parasitol., 167(2-4): 149-154. 
60. Kocan, K.M., de la Fuente, J. and Cabezas-Cruz, A. (2015) The genus Anaplasma: New challenges after reclassification. Rev. Sci. Tech., 34(2): 577-586.

61. Popov, V., Korenberg, E., Nefedova, V., Han, V., Wen, J., Kovalevskii, Y., Gorelova, N. and Walker, D. (2007) Ultrastructural evidence of the ehrlichial developmental cycle in naturally infected Ixodes persulcatus ticks in the course of coinfection with Rickettsia, Borrelia, and a Flavivirus. Vector Borne Zoonotic Dis., 7(4): 699-716.

62. Chauvin, A., Moreau, E., Bonnet, S., Plantard, O. and Malandrin, L. (2009) Babesia and its hosts: Adaptation to long-lasting interactions as a way to achieve efficient transmission. Vet. Res., 40(2): 37.

63. Yabsley, M.J. and Shock, B.C. (2013) Natural history of zoonotic Babesia: Role of wildlife reservoirs. Int. J. Parasitol. Parasites Wildl., 2: 18-31.

64. Baneth, G., Mathew, J.S., Shkap, V., Macintire, D.K., Barta, J.R. and Ewing, S.A. (2003) Canine hepatozoonosis: Two disease syndromes caused by separate Hepatozoon spp. Trends Parasitol., 19(1): 27-31.

65. Pawar, R.M., Poornachandar, A., Srinivas, P., Rao, K.R., Lakshmikantan, U. and Shivaji, S. (2012) Molecular characterization of Hepatozoon spp. Infection in endangered Indian wild felids and canids. Vet. Parasitol., 186(3-4): 475-479.

66. Furtado, M.M., Metzger, B., de Almeida Jácomo, A.T., Labruna, M.B., Martins, T.F., O'Dwyer, L.H., Paduan, K.D.S., Porfírio, G.E.O., Silveira, L., Sollmann, R., Taniwaki, S.A., Tôrres, N.M. and Neto, J.S.F. (2017) Hepatozoon spp. Infect free-ranging jaguars (Panthera onca) in Brazil. J. Parasitol., 103(3): 243-250.

67. Adao, D.E.V., Herrera, C.M.T., Galarion, L.H., Bolo, N.R., Carlos, R.S., Carlos, E.T., Carlos, S.S. and Rivera, W.L. (2017) Detection and molecular characterization of Hepatozoon canis, Babesia vogeli, Ehrlichia canis, and Anaplasma platys in dogs from Metro Manila, Philippines. Korean J. Vet. Res., 57(2): 79-88.

68. Morales-Hojas, R. (2009) Molecular systematics of filarial parasites, with an emphasis on groups of medical and veterinary importance, and its relevance for epidemiology. Infect. Genet. Evol., 9(5): 748-759.

69. Bain, O. and Babayan, S. (2003) Behaviour of filariae: Morphological and anatomical signatures of their lifestyle within the arthropod and vertebrate hosts. Filaria J., 2: 16.

70. Orihel, T.C. and Eberhard, M.L. (1998) Zoonotic filariasis. Clin. Microbiol. Rev., 11(2): 366-381.

71. Maggi, R.G., Compton, S.M., Trull, C.L., Mascarelli, P.E., Mozayeni, B.R. and Breitschwerdt, E.B. (2013) Infection with hemotropic Mycoplasma species in patients with or without extensive arthropod or animal contact. J. Clin. Microbiol., 51(10): 3237-3241.

72. Sumithra, T.G., Chaturvedi, V.K., Susan, C., Siju, S.J., Rai, A.K., Harish, C. and Sunita, S.C. (2013) Mycoplasmosis in wildlife: A review. Eur. J. Wildl. Res., 59(6): 769-781.

73. Neimark, H., Hoff, B. and Ganter, M. (2004) Mycoplasma ovis comb. Nov. (formerly Eperythrozoon ovis), an epierythrocytic agent of haemolytic anaemia in sheep and goats. Int J. Syst. Evol. Microbiol., 54(2): 365-371.

74. Santos, L.C., Cubilla, M.P., de Moraes, W., Cubas, Z.S., Oliveira, M.J., Estrada, M., Leutenegger, C.M., Sykes, J.E., Lindsay, L.L., Marcondes, M., Barros Filho, I.R. and Biondo, A.W. (2013) Hemotropic Mycoplasma in a free-ranging black howler monkey (Alouatta caraya) in Brazil. J. Wildl. Dis., 49(3): 728-731.

75. Benedetti, F., Curreli, S. and Zella, D. (2020) Mycoplasmashost interaction: Mechanisms of inflammation and association with cellular transformation. Microorganisms, 8(9): 1351.

76. Thompson, C.K. and Thompson, R.C.A. (2015) Trypanosomes of Australian mammals: Knowledge gaps regarding transmission and biosecurity. Trends Parasitol., 31(11): 553-562.
77. Truc, P., Büscher, P., Cuny, G., Gonzatti, M.I., Jannin, J., Joshi, P., Juyal, P., Lun, Z.R., Mattioli, R., Pays, E., Simarro, P.P., Teixeira, M.M.G., Touratier, L., Vincendeau, P. and Desquesnes, M. (2013) Atypical human infections by animal trypanosomes. PLoS Negl. Trop. Dis., 7(9): e2256.

78. Mehrkens, L.R., Shender, L.A., Yabsley, M.J., Shock, B.C., Chinchilla, F.A., Suarez, J. and Gilardi, K.V.K. (2013) White-nosed coatis (Nasua narica) are a potential reservoir of Trypanosoma cruzi and other potentially zoonotic pathogens in Monteverde, Costa Rica. J. Wildl. Dis., 49(4): 1014-1018.

79. Boes, K., Goncarovs, K.O., Thompson, C.A., Halik, L.A., Santos, A.P., Guimaraes, A.M.S., Miskovic, M.F., Holman, P.J., Vemulapalli, R., Messick, J.B. (2012) Identification of a Mycoplasma ovis-like organism in a herd of farmed white-tailed deer (Odocoileus virginianus) in rural Indiana. Vet. Clin. Pathol. Am. Soc. Vet. Clin. Pathol., 41(1): 77-83.

80. Campos Aquino, L.C., Hicks, C.A.E., Scalon, M.C., da M Lima, M.G., dos S Lemos, M., Paludo, G.R., Helps, C.R. and Tasker, S. (2014) Prevalence and phylogenetic analysis of haemoplasmas from cats infected with multiple species. J. Microbiol. Methods, 107: 189-196.

81. Camara Pitchenin, L., Harumi Maruyama, F., de Oliveira Morgado, T., Dutra, V. and Nakazato, L. (2019) Occurrence of hemoplasmas in free-ranging and captive wild felines. Braz. J. Infect. Dis., 23(2): 146-147.

82. Aguirre, A.A. (2009) Wild canids as sentinels of ecological health: A conservation medicine perspective. Parasit. Vectors, 2(1): S7.

83. Magalhães, L., Silveira,H.,Prestes, S., Costa Magalhães,L.K., Santana, R.A., Ramasawmy, R., Oliveira, J., Roque, C.C.R., Silva Junior, R.C.A., Fé, N., Duarte, R., Maciel, M., Ortiz, J., Morais, R., Monteiro, W.M., Guerra, J.A. and Barbosa Guerra, M.G.V. (2021) Bioecological aspects of triatomines and marsupials as wild Trypanosoma cruzi reservoirs in urban, peri-urban and rural areas in the Western Brazilian Amazon. Med. Vet. Entomol., 2021 Jan 4.

84. Rodriguez, F., Luna, B.S., Calderon, O., ManriquezRoman, C., Amezcua-Winter, K., Cedillo, J., GarciaVazquez, R., Tejeda, I.A., Romero, A., Waldrup, K., Watts, D.M., Khatchikian, C. and Maldonado, R.A. (2021) Surveillance of Trypanosoma cruzi infection in Triatomine vectors, feral dogs and cats, and wild animals in and around El Paso county, Texas, and New Mexico. PLoS Negl. Trop. Dis., 15(2): e0009147.

85. Bergner, L.M., Becker, D.J., Tello, C., Carrera, J.E. and Streicker, D.G. (2021) Detection of Trypanosoma cruzi in the saliva of diverse neotropical bats. Zoonoses Public Health, 68(3): 271-276.

86. Fetene, E., Leta, S., Regassa, F. and Büscher, P. (2021) Global distribution, host range and prevalence of Trypanosoma vivax: A systematic review and meta-analysis. Parasit. Vectors, 14(1): 80.

87. da Cunha, A.M., Muniz, J., da Cunha, A.M. and Muniz, J. (1944) Pesquisas sôbre o Endotrypanum schaudinni Mesnil e Brimont, 1908, parasita do Choloepus didactylus (L). Mem. Inst. Oswaldo Cruz, 41(1): 179-193.

88. Carme, B., De Thoisy, B., Motard, A., Aznar, C. and Vie, J.C. (2000) Parasitoses humaines et mammifères sauvages en Guyane française. Med. Trop. (Mars), 60(3): 223-231.

89. Da Silva, F.M., Noyes, H., Campaner, M., Junqueira, A.C.V., Coura, J.R., Añez, N., Shaw, J.J., Stevens, J.R. and Teixeira, M.M.G. (2004) Phylogeny, taxonomy and grouping of Trypanosoma rangeli isolates from man, triatomines and sylvatic mammals from widespread geographical origin based on SSU and ITS ribosomal sequences. Parasitology, 129(5): 549-561.

90. Ayala, S.C., D’Alessandro, A., Mackenzie, R. and Angel, D. (1973) Hemoparasite infections in 830 wild animals from the Eastern Llanos of Colombia. J. Parasitol., 59(1): 52-59.

91. Reardon, J.T. and Norbury, G. (2004) Ectoparasite and hemoparasite infection in a diverse temperate lizard 
assemblage at Macraes Flat, South Island, New Zealand. $J$. Parasitol., 90(6): 1274-1278.

92. Harris, D.J., Maia, J.P.M. and Perera, A. (2011) Molecular characterization of Hepatozoon species in reptiles from the Seychelles. J. Parasitol., 97(1): 106-110.

93. Vilcins, I.M.E., Ujvari, B., Old, J.M. and Deane, E. (2009) Molecular and morphological description of a Hepatozoon species in reptiles and their ticks in the Northern Territory, Australia. J. Parasitol., 95(2): 434-442.

94. Dawson, J.E., Warner, C.K., Baker, V., Ewing, S.A., Stallknecht, D.E., Davidson, W.R., Kocan, A.A., Lockhart, J.M. and Olson, J.G. (1996) Ehrlichia-like 16S rDNA sequence from wild white-tailed deer (Odocoileus virginianus). J. Parasitol., 82(1): 52-58

95. Soares, H.S., Marcili, A., Barbieri, A.R.M., Minervino, A.H.H., Malheiros, A.F., Gennari, S.M. and Labruna, M.B. (2017) Novel Anaplasma and Ehrlichia organisms infecting the wildlife of two regions of the Brazilian Amazon. Acta Trop., 174: 82-87.

96. Maamun, J.M., Suleman, M.A., Akinyi, M., Ozwara, H., Kariuki, T. and Carlsson, H.E. (2011) Prevalence of Babesia microti in free-ranging baboons and African green monkeys. J. Parasitol., 97(1): 63-67.

97. Michel, A.O., Mathis, A. and Ryser-Degiorgis, M.P. (2014) Babesia spp. In European wild ruminant species: Parasite diversity and risk factors for infection. Vet. Res., 45(1): 65.

98. Moody, A. H. and Chiodini, P. L. (2000) Methods for the detection of blood parasites. Clin. Lab. Haematol., 22(4):189-201.

99. Valkiūnas, G., Santiago-Alarcon, D., Levin, I.I., Iezhova, T.A. and Parker, P.G. (2010) A new Haemoproteus species (Haemosporida: Haemoproteidae) from the endemic Galapagos dove Zenaida galapagoensis, with remarks on the parasite distribution, vectors, and molecular diagnostics. J. Parasitol., 96(4): 783-792.

100. Wang, G., Villafuerte, P., Zhuge, J., Visintainer, P. and Wormser, G.P. (2015) Comparison of a quantitative PCR assay with peripheral blood smear examination for detection and quantitation of Babesia microti infection in humans. Diagn. Microbiol. Infect. Dis., 82(2): 109-113.

101. Teal, A.E., Habura, A., Ennis, J., Keithly, J.S. and MadisonAntenucci, S. (2012) A new real-time PCR assay for improved detection of the parasite Babesia microti. J. Clin. Microbiol., 50(3): 903-908.

102. Gabrielli, S., Kumlien, S., Calderini, P., Brozzi, A., Iori, A. and Cancrini, G. (2010) The first report of Hepatozoon canis identified in Vulpes vulpes and ticks from Italy. Vector Borne Zoonotic Dis. Larchmt. N, 10(9): 855-859.

103. Bouer, A., André, M.R., Gonçalves, L.R., de Cássia Luzzi, M., de Oliveira, J.P., Rodrigues, A.C., de Melo Varani, A., de Miranda, V.F.O., Perles, L., Werther, K. and Machado, R.Z. (2017) Hepatozoon caimani in Caiman crocodilus yacare (Crocodylia, Alligatoridae) from North Pantanal, Brazil. Rev. Bras. Parasitol. Vet., 26(3): 352-358.

104. Úngari, L.P., Netherlands, E.C., Quagliatto Santos, A.L., de Alcantara, E.P., Emmerich, E., da Silva, R.J. and O'Dwyer, L.H. (2020) A new species, Dactylosoma piperis n. spp. (Apicomplexa, Dactylosomatidae), from the pepper frog Leptodactylus labyrinthicus (Anura, Leptodactylidae) from Mato Grosso State, Brazil. Parasite, 27: 73.

105. Link, A., Palacios, E., Cortés-Ortiz, L., Stevenson, P.R., Cornejo, F.M., Mittermeier, R.A., Shanee, S., de la Torre, S., Boubli, J.P., Guzmán-Caro, D.C., Moscoso, P. and Urbani, B. (2021) Alouatta seniculus (Amended Version of 2020 Assessment). The IUCN Red List of Threatened Species. Available from: https://www.iucnredlist.org/species/70547436/190432393. Retrieved on 28-05-2021.

106. Pazmiño-Otamendi, G. and Guerra-Correa, E. (2019) Boa Constrictor. Reptiles del Ecuador. Museo de Zoología, Pontificia Universidad Católica del Ecuador. Available from: https://www.bioweb.bio/faunaweb/reptiliaweb/ FichaEspecie/Boa\%20constrictor. Retrieved on 28-05-2021.
107. Balaguera-Reina, S.A. and Velasco, A. (2019) Caiman crocodilus. The IUCN Red List of Threatened Species. Available from: https://www.iucnredlist.org/species/46584/3009688. Retrieved on 28-05-2021.

108. de la Torre, S., Shanee, S., Palacios, E., Calouro, A.M., Messias, M.R. and Valença-Montenegro, M.M. (2021) Cebuella pygmaea (Amended Version of 2020 Assessment). The IUCN Red List of Threatened Species. Available from: https://www.iucnredlist.org/species/136926/191707442. Retrieved on 28-05-2021.

109. Link, A., Boubli, J.P., Mittermeier, R.A., Urbani, B., Ravetta, A.L., Guzmán-Caro, D.C., Muniz, C.C. and Lynch Alfaro, J.W. (2021) Cebus albifrons (Amended Version of 2020 Assessment). The IUCN Red List of Threatened Species. Available from: https://www.iucnredlist.org/species/39951/191703935. Retrieved on 28-05-2021.

110. Boubli, J.P., Stevenson, P.R., Palacios, E., de la Torre, S., Ravetta, A.L., Messias, M.R., Carvalho, A.S. and Mittermeier, R.A. (2021) Sapajus apella (Amended Version of 2020 Assessment). The IUCN Red List of Threatened Species 2021. Available from: https://www.iucnredlist.org/ species/172351505/192594550. Retrieved on 28-05-2021.

111. Chiarello, A. and Plese, T. (2014) Choloepus didactylus. The IUCN Red List of Threatened Species. Available from: https://www.iucnredlist.org/species/4777/47439542. Retrieved on 28-05-2021.

112. Plese, T. and Chiarello, A. (2014) Choloepus hoffmanni. The IUCN Red List of Threatened Species. Available from: https://www.iucnredlist.org/species/4778/47439751. Retrieved on 28-05-2021.

113. Stevenson, P.R., Defler, T.R., de la Torre, S., Moscoso, P., Palacios, E., Ravetta, A.L., Vermeer, J., Link, A., Urbani, B., Cornejo, F.M., Guzmán-Caro, D.C., Shanee, S., Mourthé, I., Muniz, C.C., Wallace, R.B. and Rylands, A.B. (2021) Lagothrix lagothricha (Amended Version of 2020 Assessment). The IUCN Red List of Threatened Species. Available from: https://www.iucnredlist.org/species/160881218/192309103. Retrieved on 28-05-2021.

114. Paviolo, A., Crawshaw, P., Caso, A., de Oliveira, T., LopezGonzalez, C.A., Kelly, M., De Angelo, C. and Payan, E. (2015) Leopardus pardalis (Errata Version Published in 2016). The IUCN Red List of Threatened Species. Available from: https://www.iucnredlist.org/species/11509/97212355. Retrieved on 28-05-2021.

115. Payan, E. and de Oliveira, T. (2016) Leopardus tigrinus. The IUCN Red List of Threatened Species. Available from: https://www.iucnredlist.org/species/54012637/50653881. Retrieved on 28-05-2021.

116. Lizcano, D. and Alvarez, S.J. (2016) Mazama rufina. The IUCN Red List of Threatened Species. Available from: https://www.iucnredlist.org/species/12914/22165586. Retrieved on 28-05-2021.

117. Ross, J.P. (2000) Melanosuchus niger. The IUCN Red List of Threatened Species. Available from: https://www.iucnredlist.org/species/13053/3407604. Retrieved on 28-05-2021.

118. Emmons, L. and Helgen, K. (2016) Nasua nasua. The IUCN Red List of Threatened Species. Available from: https:// www.iucnredlist.org/species/41684/45216227. Retrieved on 28-05-2021.

119. Gallina, S. and Lopez Arevalo, H. (2016) Odocoileus virginianus. The IUCN Red List of Threatened Species. Available from: https://www.iucnredlist.org/species/42394/22162580. Retrieved on 28-05-2021.

120. Quigley, H., Foster, R., Petracca, L., Payan, E., Salom, R. and Harmsen, B. (2017) Panthera onca (errata version published in 2018). The IUCN Red List of Threatened Species. Available from: https://www.iucnredlist.org/species/15953/123791436. Retrieved on 28-05-2021.

121. Helgen, K., Kays, R. and Schipper, J. (2016) Potos flavus. The IUCN Red List of Threatened Species 2016. Available from: https://www.iucnredlist.org/species/41679/45215631. Retrieved on 28-05-2021. 
122. Barrio, J. and Tirira, D.G. (2019) Pudu mephistophiles. The IUCN Red List of Threatened Species. Available from: https://www.iucnredlist.org/species/18847/22163836. Retrieved on 28-05-2021.

123. Nielsen, C., Thompson, D., Kelly, M. and LopezGonzalez, C.A. (2015) Puma concolor (Errata Version Published in 2016). The IUCN Red List of Threatened Species. Available from: https://www.iucnredlist.org/species/18868/97216466. Retrieved on 28-05-2021.

124. Caso, A., de Oliveira, T. and Carvajal, S.V. (2015) Herpailurus yagouaroundi. The IUCN Red List of Threatened Species. Available from: https://www.iucnredlist.org/species/9948/50653167. Retrieved on 28-05-2021.

125. Heymann, E.W., Ravetta, A.L., Mittermeier, R.A., Alonso, A.C. and Moura, E.F. (2021) Leontocebus fuscicollis (Amended Version of 2020 Assessment). The IUCN Red List of Threatened Species. Available from: https://www. iucnredlist.org/species/160885500/192315580. Retrieved on 28-05-2021.

126. Silva Júnior, J.S., Mittermeier, R.A., Lynch Alfaro, J.W., Valença-Montenegro, M.M. and Carvalho, A.S. (2021) Saimiri sciureus (Amended Version of 2020 Assessment). The IUCN Red List of Threatened Species. Available from: https://www.iucnredlist.org/species/43968/192584742. Retrieved on 28-05-2021.

127. Cuarón, A.D., Shedden, A., Rodríguez-Luna, E., de Grammont, P.C. and Link, A. (2020) Alouatta palliata ssp. aequatorialis. The IUCN Red List of Threatened Species. Available from: https://www.iucnredlist.org/species/919/17979025. Retrieved on 13-07-2021

128. Espinoza Villar, J.C., Ronchail, J., Guyot, J.L., Cochonneau, G., Naziano, F., Lavado, W., De Oliveira, E., Pombosa, R. and Vauchel, P. (2009) Spatio-temporal rainfall variability in the Amazon basin countries (Brazil, Peru, Bolivia, Colombia, and Ecuador). Int. J. Climatol., 29(11): 1574-1594.

129. Confalonieri, U.E.C., Margonari, C. and Quintão, A.F. (2014) Environmental change and the dynamics of parasitic diseases in the Amazon. Acta Trop., 129: 33-41.

130. Dantas-Torres, F. (2015) Climate change, biodiversity, ticks and tick-borne diseases: The butterfly effect. Int. J. Parasitol. Parasites Wildl., 4(3): 452-461.

131. Parola, P., Socolovschi, C., Jeanjean, L., Bitam, I., Fournier, P.E., Sotto, A., Labauge, P. and Raoult, D. (2008)
Warmer weather linked to tick attack and emergence of severe rickettsioses. PLoS Negl. Trop. Dis., 2(11): e338.

132. Moore, S., Shrestha, S., Tomlinson, K.W. and Vuong, H. (2012) Predicting the effect of climate change on African trypanosomiasis: Integrating epidemiology with parasite and vector biology. J. R. Soc. Interface, 9(70): 817-830.

133. Daszak, P., Cunningham, A.A. and Hyatt, A.D. (2000) Emerging infectious diseases of wildlife--threats to biodiversity and human health. Science, 287(5452): 443-449.

134. Van Der Hoek, Y. (2017) The potential of protected areas to halt deforestation in Ecuador. Environ. Conserv., 44(2): 124-130.

135. Tapia-Armijos, M.F., Homeier, J., Espinosa, C.I., Leuschner, C. and de la Cruz, M. (2015) Deforestation and forest fragmentation in South Ecuador since the 1970s-losing a hotspot of biodiversity. PLoS One, 10(9): e0133701.

136. Lippi, C.A., Stewart-Ibarra, A.M., Loor, M.E.F., Zambrano, J.E.D., Lopez, N.A.E., Blackburn, J.K. and Ryan, S.J. (2019) Geographic shifts in Aedes aegypti habitat suitability in Ecuador using larval surveillance data and ecological niche modeling: Implications of climate change for public health vector control. PLoS Negl. Trop. Dis., 13(4): e0007322.

137. Plowright, R.K., Parrish, C.R., McCallum, H., Hudson, P.J., Ko, A.I., Graham, A.L. and Lloyd-Smith, J.O. (2017) Pathways to zoonotic spillover. Nat. Rev. Microbiol., 15(8): 502-510.

138. Woolhouse, M.E.J. and Gowtage-Sequeria, S. (2005) Host range and emerging and reemerging pathogens. Emerg. Infect. Dis., 11(12): 1842-1847.

139. Keesing, F., Belden, L.K., Daszak, P., Dobson, A., Harvell, C.D., Holt, R.D., Hudson, P., Jolles, A., Jones, K.E., Mitchell, C.E., Myers, S.S., Bogich, T. and Ostfeld, R.S. (2010) Impacts of biodiversity on the emergence and transmission of infectious diseases. Nature, 468(7324): 647-652.

140. Rhyan, J.C. and Spraker, T.R. (2010) Emergence of diseases from wildlife reservoirs. Vet. Pathol., 47(1): 34-39.

141. Manlove, K.R., Walker, J.G., Craft, M.E., Huyvaert, K.P., Joseph, M.B., Miller, R.S., Nol, P., Patyk, K.A., O’Brien, D., Walsh, D.P. and Cross, P.C. (2016) "One Health" or three? Publication silos among the one health disciplines. PLoS Biol., 14(4): e1002448.

142. Jenkins, E.J., Simon, A., Bachand, N. and Stephen, C. (2015) Wildlife parasites in a one health world. Trends Parasitol., 31(5): 174-180.

\section{$* * * * * * * *$}

